\title{
Role of courts in interpreting local government's environmental powers in South Africa
}

Commonwealth Journal of Local Governance

Issue 18: December 2015

http://epress.lib.uts.edu.au/ojs/index.php/cjlg

\section{Oliver Fuo}

Department of Public Law

Faculty of Law

University of Free State, South Africa

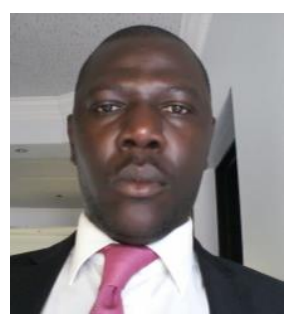

\begin{abstract}
Local government in post-apartheid South Africa has undergone fundamental transformation. This is evident from its extensive governing powers and functions and its expanded developmental mandate. At the forefront of sustainable development, municipalities have legislative and executive powers to administer the matters listed in Schedules $4 B$ and $5 B$ of the Constitution of the Republic of South Africa, 1996. Moreover, matters listed in Schedules 4A and 5A of the Constitution can be assigned to municipalities by national and provincial governments. Like other spheres of government, municipalities are obliged to contribute towards realising $s 24$ of the Constitution - guaranteeing environmental rights. However, the exact contours of their powers in promoting the objectives of $s 24$ of the Constitution are ill-defined and subject to ongoing definition by way of legislation, policies and case-law. This article argues that environmental litigation presents courts an opportunity to further redefine the powers of municipalities in fostering constitutional environmental objectives in South Africa. Drawing from Le Sueur and Another v eThekwini Municipality and Others [2013] ZAKZPHC 6 (30 January 2013), this article demonstrates how courts can play an important role in clarifying the environmental powers and functions of municipalities in South Africa. This article is based on a review of legal and extra-legal sources.
\end{abstract}

\section{Introduction}

Local government in post-apartheid South Africa has undergone fundamental constitutional transformation (Fedsure Life Assurance case 1998, pars 35-38; Fuo 2014, pp. 86-117). Local government is a distinct, interdependent, and interrelated sphere of government with extensive governing powers and functions as well as an expanded developmental mandate (Constitution of the Republic of South Africa 1996, ss 151-156; de Visser 2005, p. 65; du Plessis 2010, pp. 265-269; Blue Moonlight case 2012, par 57 and 66; City of Cape Town v Robertson 2005, pars 55-60). Local

(C) 2015 Oliver Fuo. This is an Open Access article distributed under the terms of the Creative Commons Attribution 4.0 Unported (CC BY 4.0) License (https://creativecommons.org/licenses/by/4.0/), allowing third parties to copy and redistribute the material in any medium or format and to remix, transform, and build upon the material for any purpose, even commercially, provided the original work is properly cited and states its license.

Citation: Commonwealth Journal of Local Governance 2015, 18: 4840, - http://dx.doi.org/10.5130/cjlg.v0i18.4840 
government's expanded developmental mandate obliges municipalities to provide services to communities in a sustainable manner (s 152(1)(b) of the Constitution; Joseph case 2010, pars 34-40) ${ }^{1}$ provide democratic and accountable government for local communities (s 152(1)(a) of the Constitution; de Visser 2005, p. 70); promote socio-economic development (s 152(1)(c) and 153 (a) of the Constitution); ${ }^{2}$ promote a safe and healthy environment (s 152(d) of the Constitution); encourage the involvement of communities and community organisations in the matters of local government (s 152(1)(e) of the Constitution; Joseph case 2010, pars 27, 34-40); participate in national and provincial development programmes (s 153(b) of the Constitution); and contribute (together with other spheres of government and organs of state) towards the realisation of, inter alia, the constitutional environmental right (ss 2, 7(2) and 24 of the Constitution). ${ }^{3}$

Sections 24 and 7(2) of the Constitution obliges the state (inclusive of municipalities) to respect, protect, promote and fulfil the rights in the Bill of Rights and further requires government to adopt legislative and other measures to realise the right of everyone to an environment that is not harmful to their health and well-being. These obligations apply to, and bind the legislative and executive arms of government in all spheres (de Visser 2003, pp. 201-215). In the context of local government, sections 4(2)(j) and 23(1)(c) of the Systems Act explicitly obliges municipalities to contribute, together with other organs of state, to the progressive realisation of the fundamental rights contained in, inter alia, section 24 of the Constitution. The direct implication of these statutory provisions is that municipalities are legally bound to realise aspects of the constitutional environmental right that fall within their shared or exclusive areas of competence (Steytler and de Visser 2009, pp. 9-12). The general obligation that local government should promote sustainable development arguably makes environmental protection a core mandate of local government (du Plessis 2008, pp. 10-13, 337-516; du Plessis and du Plessis 2011, p. 424). Municipalities are therefore obliged to contribute towards realising the objectives of s 24 of the Constitution.

Despite the above obligations, on face value, Schedules $4 \mathrm{~B}$ and $5 \mathrm{~B}$ of the Constitution give an indication of the areas of environmental competence for municipalities. However, the exact contours of their powers in promoting the objectives of section 24 of the Constitution are subject to ongoing definition by way of legislation, policies and interpretation by courts. This article argues that courts have an important role to play in redefining the environmental powers and functions of municipalities

\footnotetext{
${ }^{1}$ Ch 8 of the Local Government Municipal Systems Act 32 of 2000.

${ }^{2}$ See Preamble and s 4(2)(g) of the Local Government: Municipal Systems Act 32 of 2000.

${ }^{3} \mathrm{~S} 24$ of the Constitution provides that "Everyone has the right-(a) to an environment that is not harmful to their health or wellbeing; and $(b)$ to have the environment protected for the benefit of present and future generations, through reasonable legislative and other measures that (i) prevent pollution and ecological degradation; (ii) promote conservation; and (iii) secure ecologically sustainable development and use of natural resources while promoting justifiable economic and social development."
} 
beyond the rigid walls of Schedules $4 \mathrm{~B}$ and $5 \mathrm{~B}$ of the Constitution. This article is divided into four main parts. The first part begins by highlighting the role of courts in realising the objectives of the constitutional environmental right in South Africa. The second part provides an overview of the 'original' environmental powers and functions of municipalities as outlined in the Constitution. The third part explores additional sources of local government's powers in environmental matters. Using Le Sueur and Another v eThekwini Municipality and Others, ${ }^{4}$ the fourth part shows how litigation has already been used to expand the environmental powers and functions of municipalities beyond Schedules 4B and 5B of the Constitution. Drawing inspiration from the Le Sueur case, this article argues that environmental litigation presents courts with the opportunity to contribute towards clarifying the constitutional environmental powers and functions of South African municipalities. This article is based on a review of primary and secondary sources of law.

\section{Courts and environmental protection in South Africa}

South African courts have an important role to play in ensuring that the objectives of the constitutional environmental right are realised (Kidd 2006, pp. 72-87; du Plessis 2008, pp. 343-344; Kotze and du Plessis 2010, pp. 160-162). ${ }^{5}$ In the Fuel Retailers case, ${ }^{6}$ the Constitutional Court affirmed that the role of the courts is very important in the context of the protection of the environment and giving effect to the principle of sustainable development. The Court observed that the importance of environmental protection cannot be gainsaid given that the enjoyment of other rights in the Bill of Rights is dependent on the realisation of the environmental right. The Court indicated that the trusteeship position of courts carries with it the responsibility to look after the environment for the benefit of present and future generations (Fuel Retailers case, par 102).

Proceeding from the above premise, the Court affirmed that an independent judiciary and the judicial process are vital for the interpretation, implementation, development and enforcement of environmental law (Fuel Retailers case, par 103). The Court stressed that when the need arises for courts to intervene in order to protect the environment, "they should not hesitate to do so" (Fuel Retailers, par 104). In this context, it has been argued by Kotze and du Plessis (2010, pp. 159-160) that the role of courts is generally four-fold: Firstly, courts 'uphold' environmental law in practice by carefully considering rights and interests and then making reasonable, just, lawful and equitable findings; secondly, courts solve environmental disputes between litigants by interpreting and applying the law - giving effect to one of the basic functions of law, maintaining order and social control;

\footnotetext{
${ }^{4}$ Le Sueur and Another v eThekwini Municipality and Others [2013] ZAKZPHC 6 (30 January 2013).

${ }^{5}$ For details on the foundation, hierarchy of courts and administration of justice in South Africa, see Ch 8 of the Constitution.

${ }^{6}$ Fuel Retailers Association of Southern Africa v Director-General: Environmental Management, Department of Agriculture, Conservation and Environment, Mpumalanga Province and Others 2007 (10) BCLR 1059 (CC).
} 
thirdly, courts contribute to the deepening of environmental law discourse through performing the previous two roles. This gives them an opportunity to analyse, interpret, explain and refine existing environmental law. Finally, in deepening environmental law discourse, courts contribute to lawmaking (Kotze and du Plessis 2010, pp. 159-160). In the context of the country's three-sphere government, the exercise of the court's role in environmental protection may lead to a clearer understanding of the duties as well as powers and functions of each sphere of government.

In South Africa, legal scholars have traditionally placed much emphasis on the role of courts in developing the substantive content of the constitutional environmental right and in explaining the legal environmental duties imposed by the Constitution on the government - in terms of the wording of the constitutional environmental right and the typology of respect, protect, promote and fulfil (de Wet and du Plessis 2010, pp. 345-376; Kotze and du Plessis 2010, pp. 157-176; du Plessis 2011, pp. 279-307). In this article, I argue that litigation presents courts the opportunity to use their position to clarify the powers of municipalities in furthering the objectives of section 24 of the Constitution.

\section{Original environmental powers and functions of municipalities}

A central feature of the previous system of local government was its lack of self-governing powers. Local government was subjected to strict control by provincial and national governments and bylaws passed by local authorities were, for example, subject to the approval of the Provincial Administrator (Fuo 2014, pp. 78-81). This stringent control over local government's law-making powers reduced local authorities to decentralised executive agencies for relevant central government departments (Fuo 2014, pp. 78-81). However, as part of the democratic transformation, the self-governing power of local government is now entrenched in section 151(2) and (3) of the Constitution. In the Fedsure Life Assurance case, ${ }^{7}$ the Court described the newly established constitutional powers of local government within the context of the Interim Constitution as follows:

The constitutional status of local government is thus materially different to what it was when parliament was supreme, when not only the powers but the very existence of local government depended entirely on superior legislatures. The institution of elected local government could then have been terminated at any time and its functions entrusted to administrators appointed by central or provincial governments. That is no longer the position. Local governments have a place in the constitutional order...and are entitled to certain powers, including the power to make bylaws and impose rates.

The significance of the above extract is that the core functions of local government as defined by the Constitution cannot be removed or amended by ordinary statute or provincial legislation. The powers and functions of local government can only be changed by a constitutional amendment (de Visser 2005, p. 114).

\footnotetext{
${ }^{7}$ Fedsure Life Assurance Ltd and Others v Greater Johannesburg Transitional Metropolitan Council and Others 1998 (12) BCLR 1458 at par 36.
} 
In the City of Cape Town and Other $v$ Robertson, $2005,{ }^{8}$ the Court reiterated the extent of local government's transformation, powers and functions when it asserted that:

The Constitution has moved away from a hierarchical division of governmental power and has ushered in a new vision of government in which the sphere of local government is interdependent, 'inviolable and possesses the constitutional latitude within which to define and express its unique character' subject to constraints permissible under our Constitution. A municipality under our Constitution is not a mere creature of statute otherwise moribund save if imbued with power by provincial and national legislation. A municipality enjoys 'original' and constitutionally entrenched powers, functions, rights and duties that may be qualified or constrained by law and only to the extent the Constitution permits. Now the conduct of the municipality is not always invalid only for the reason that no legislation authorises it. Its powers may derive from the Constitution or from legislation of a competent authority or from its own laws.

The above extract highlights the extent of constitutional transformation of local government in South Africa. It demonstrates inter alia that local government is entrenched in the Constitution as an interdependent sphere of government, enjoying a certain degree of autonomy. While demonstrating that the transformation established a co-relationship between local, provincial and national governments (Malan 2005, p. 227; du Plessis 2008, p. 425), it makes it clear that local government has 'original' powers and functions that can only be constrained within the ambit of the Constitution.

Generally, the original powers and functions of local government are set out in section 156 of the Constitution. According to section 156(1) and (2) of the Constitution, a municipality has executive and legislative authority in respect of, and has the right to administer the local government matters listed in Part B of Schedule 4 and Part B of Schedule 5 of the Constitution. The matters listed in these constitutional Schedules constitute the original powers of local government because they are directly sourced from the Constitution (Christmas and de Visser 2009, pp. 107-119). Matters listed in these Schedules are outlined in Table 1 below.

Although the Constitutional Court has indicated in the context of the right of access to housing that section 156 and Schedules 4B and 5B of the Constitution are not the only source of local government's powers (Blue Moonlight case 2012, pars 21-29, 46-67), these provisions show functional areas where municipalities have executive and legislative (law-making) powers and confirm local government's distinctiveness as a sphere of government (de Visser 2009, p. 12; Christmas and de Visser 2009, p. 111).

\footnotetext{
${ }^{8}$ City of Cape Town and Other v Robertson and Other 2005 (2) SA 323 (CC) at par 60. Own emphasis.
} 
Table 1: Legislative competence

\begin{tabular}{|l|l|}
\hline $\begin{array}{l}\text { Schedule 4B of Constitution: Local government's } \\
\text { areas of legislative competence }\end{array}$ & $\begin{array}{l}\text { Schedule 5B of Constitution: Local government matters } \\
\text { over which provinces have legislative competence }\end{array}$ \\
\hline Air pollution & Beaches and amusement facilities \\
Building regulations & Billboards and the display of advertisements in public places \\
Child care facilities & Cemeteries, funeral parlours and crematoria \\
Electricity and gas reticulation & Cleansing \\
Fire-fighting services & Control of public nuisances \\
Local tourism & Control of undertakings that sell liquor to the public \\
Municipal airports & Facilities for the accommodation, care and burial of animals \\
Municipal planning & Fencing and fences \\
Municipal health services & Licensing of dogs \\
Municipal public transport & Licensing and control of undertakings selling food to the public \\
Municipal public works & Local amenities \\
Pontoons, ferries, jetties, piers and harbours, excluding & Local sport facilities \\
the regulation of international/national shipping matters & Markets \\
Stormwater management systems in built-up areas & Municipal abattoirs \\
Trading regulations & Municipal parks and recreation \\
Water and sanitation services limited to potable water & Municipal roads \\
supply systems & Noise pollution \\
Domestic waste-water and sewage disposal systems & Pounds \\
& Public places \\
& Refuse removal, refuse dumps and solid waste disposal \\
& Street trading \\
& Street lighting \\
\hline
\end{tabular}

From the above table, it appears that the original powers and functions of municipalities in the area of environmental protection are limited to "brown issues ${ }^{9}$ such as: air and noise pollution; municipal health services; sanitation services; refuse removal, refuse dumps, and solid waste disposal; fire fighting; sewage disposal; and municipal planning. It is apparent that some of these functions are interrelated. In addition, it is important to note that some of the listed functions are open to interpretation. The 2004 White Paper on Municipal Service Partnerships notes that:

The meaning of these functions is not defined in the Constitution or elsewhere. At times a co-operative process has been required in order to determine functional boundaries with other spheres of government in certain areas including health care, housing and transport. Currently the Department is considering the meaning of these functions and is clarifying boundaries (Department of Provincial and Local Government 2004, p. 4).

The co-operative process of interpreting these functions does not always result in consensus. ${ }^{10}$ However, it should be noted that a purposive interpretation of the above listed functions, together with the Bill of Rights and objectives of developmental local government, can provide municipalities

\footnotetext{
${ }^{9}$ In environmental discourse, a difference is often drawn between 'brown' and 'green' issues. While green issues typically cover nature conservation, brown issues deal with urban environmental challenges such as access to services (such water, energy and sanitation) waste management and air pollution, for example. See Cock J. 2004. Connecting the red, brown and green: The environmental justice movement in South Africa. Durban: University of KwaZulu-Natal at 2-3.

${ }^{10}$ For example, it has taken a number of cases for the courts to clarify the planning powers of municipalities visà-vis other spheres of government. See Maccsand (Pty) Ltd v City of Cape Town and Others 2012 (7) BCLR 690 (CC); Minister of Local Government, Environmental Affairs and Development Planning, Western Cape v Habitat Council and Others 2014 (4) SA 437 (CC); Minister of Local Government, Western Cape v Lagoonbay Lifestyle Estate (Pty) Ltd and Others 2014 (1) SA 521 (CC); Minister of Local Government, Environmental Affairs and Development Planning, Western Cape v Habitat Council and Others 2014 (4) SA 437 (CC).
} 
legislative and executive competence to cater for other environmental related functions that are not explicitly listed in Schedules 4B and 5B of the Constitution. For example, as it will become evident from the discussion below that municipal planning has been interpreted as a function which gives legislative and executive competence to municipalities in biodiversity protection.

According to Steytler and Fessha (2005, p. 2), section 156 of the Constitution shows that provincial and national governments "have only limited supervisory authority" with regard to the functional areas in Schedules 4B and 5B of the Constitution. This means that the other spheres of government retain the powers to support and monitor the extent to which municipalities perform their environmental related functions listed in Schedules 4B and 5B of the Constitution (Steytler and Fessha 2005, p. 2). Due to the fact that the original powers and functions of municipalities are rooted in the Constitution, they cannot be removed or amended by national or provincial legislation except by an amendment of the Constitution itself (de Visser 2005, pp. 113-114). To de Visser (2005, p. 114), this is the most significant and fundamental feature of the institutional integrity of local government. Besides, section 156(5) grants municipalities "the right to exercise any power concerning a matter reasonably necessary for, or incidental to, the effective performance of its functions." de Visser (2005, pp. 121-122) refers to powers derived from section 156(5) of the Constitution by municipalities as 'incidental' powers.

It is important to note that section 229(1)(a) and (b) of the Constitution accords municipalities the powers to generate revenue through rates and taxes in order to be able to finance its activities. ${ }^{11}$ This means that municipalities with a viable economic base can self-fund environmental programmes adopted to give effect to their constitutional environmental mandate. The constitutional powers accorded to municipalities to generate internal revenue is given legislative effect by, inter alia, sections 4(1)(c) and 71 of the Systems Act. The power of municipalities to generate internal revenue has been confirmed by the Constitutional Court in a number of cases. ${ }^{12}$

In addition to the original environmental powers and functions of municipalities outlined in Schedules $4 \mathrm{~B}$ and $5 \mathrm{~B}$ of the Constitution, additional environmental powers and functions can be assigned to municipalities. The paragraphs that follow highlights the relevant constitutional provision and

\footnotetext{
${ }^{11}$ See the Municipal Fiscal Powers and Functions Act 12 of 2007, which seeks to clarify the powers and functions of municipalities in this regard. The Preamble provides that the Act seeks to "regulate the exercise by municipalities of their power to impose surcharges on fees for services provided under section 229(1)(a) of the Constitution; to provide for the authorisation of taxes, levies and duties that municipalities may impose under section 229(1)(b) of the Constitution; and for matters connected therewith."

${ }^{12}$ See Mkontwana $v$ Nelson Mandela Metropolitan Municipality 2005 (2) BCLR 150 (CC) at pars 61, 64 and 73; Rates Action Group v City of Cape Town [2007] 1 All SA 233 (SCA) at pars 1-20; City of Cape Town Others v Robertson, pars 61-71; Joseph and Others, pars 53 and 54.
} 
demonstrates that national legislation and policies usually require municipalities to execute environmental functions that go beyond their 'original' powers and functions.

\section{Environmental powers beyond constitutional schedules}

One of the novel features that became applicable at the local government level following the process of constitutional transformation is the principle of institutional subsidiarity (Carpenter 1999, pp. 4546; de Visser 2008, p. 2; de Visser 2010, pp. 90-115). Although the Constitution does not make express reference to 'subsidiarity', it is believed that this principle influenced its design in terms of allocating and safeguarding powers between the three spheres of government (de Visser 2010, p. 100). In this context for example, de Visser $(2008$, p. 3) has situated the subsidiarity principle within section 156(4) of the Constitution which provides that:

The national and provincial governments must assign to a municipality, by agreement and subject to any conditions, the administration of a matter listed in Part A of Schedule 4 and Part A of Schedule 5 which necessarily relates to local government, if -

(a) that matter would most effectively be administered locally; and if

(b) the municipality has the capacity to administer.

The above provision embodies the allocative institutional subsidiarity principle in that it requires national and provincial spheres of government to assign or allocate to municipalities certain (environmental) functions that can be better discharged by municipalities, subject to the satisfaction of certain conditions (de Visser 2008, p. 7, p. 12). De Visser (2010, p. 112) indicates that the wordings of section 156(4) of the Constitution show that assignment is compulsory once the requirements have been met. Assignments under section 154(6) of the Constitution can be general to all municipalities or to a specific municipality (de Visser 2008, pp. 29-30). Where there is legislative assignment, full legislative and executive powers over an environmental function are transferred to a municipality. In the case of executive assignments, only the executive/administrative power over a specific environmental function is assigned to a municipality. Sections 9 to 10 of the Systems Act outline the procedure for assigning powers to municipalities. It is important to note that district municipalities can also transfer some core functions to a local municipality (de Visser 2008, pp. 29-30). From section 156(4) of the Constitution, it is clear that, in addition to matters listed in Schedules 4B and 5B of the Constitution, there is the possibility for more environmental functions contained in Part A of Schedule 4 and Part A of Schedule 5 to be assigned to local government (de Visser 2005, pp. 142-143). ${ }^{13}$

\footnotetext{
${ }^{13}$ Schedule 4A of the Constitution outlines areas of concurrent national and provincial legislative competence. On the other hand, Schedule 5A outlines the areas of exclusive provincial legislative competence.
} 
Besides section 156(4) of the Constitution, the Bill of Rights has a direct bearing on local government's environmental powers and duties. ${ }^{14}$ As indicated above, in addition to the duty to respect, protect, promote and fulfil the section 24 constitutional environmental right, municipalities are equally obliged to adopt and implement reasonable legislative and other measures (such as bylaws, policies, plans) that will contribute towards the realisation of an environment that is not harmful to health and well-being (du Plessis 2010, pp. 266-268; Fuo 2013, pp. 13-15). Measures adopted to give effect to section 24 of the Constitution should also be directed towards preventing pollution and ecological degradation; promoting conservation; and securing ecologically sustainable development and use of natural resources while promoting justiciable socio-economic development.

The jurisprudence of the Constitutional Court also suggests that reasonable legislative and other measures adopted to realise all socio-economic rights must clearly allocate responsibilities and tasks to the various spheres of government, including the financial resources necessary for their execution. ${ }^{15}$ However, the degree of responsibility of the three spheres of government may differ, especially in accordance with their related powers and functions and access to resources. As argued elsewhere (Fuo 2013, pp. 1-44), the positive duty to adopt reasonable legislative and executive measures to give effect to section 24 of the Constitution amounts to a constitutional delegation of authority to the legislative and executive branches of government - in all spheres - to give effect to relevant rights through legislation and policies, for example. This constitutional delegation of authority is relevant and applicable to all municipalities. In this regard, it has been argued that "local authorities can be held liable, even if only to some degree, should they not adhere to the duties created by section 24" of the Constitution (du Plessis 2011, p. 268).

It must be stressed that although the Constitutional Court indicated in the Fuel Retailers case that municipalities are obliged to promote the objectives of sustainable development, it has not precisely defined the responsibility of municipalities in realising section 24 of the Constitution. This is not strange given that the Court is yet to give content to the scope or normative meaning of the section 24 constitutional environmental rights. However, the novel duty imposed on local government to promote a safe and healthy environment suggests that municipalities should strive to ensure that the inter-relationship between people and the natural environment is such that the environment is not and does not become harmful to human health (du Plessis 2011, p. 293). Municipalities should manage the environment in such a manner that it can cater for peoples' dependence on resources such as drinking water, food and air to breathe (du Plessis 2011, p. 293).

\footnotetext{
${ }^{14}$ This has already been the focus of an LLD thesis. See du Plessis Fulfilment of South Africa's Constitutional Environmental Right in the Local Government Sphere (2008, North-West University, Potchefstroom).

${ }^{15}$ See Government of the Republic of South Africa and Others v Grootboom and Others 200011 BCLR 1169 (CC) para 38.
} 
Managing the environment goes beyond the conservation of natural resources and has much to do with peoples' health, access to water and sanitation, as well as land use (du Plessis 2011, p. 285; Urquhart and Atkinson 2002, pp. 20-21). The duty to promote a healthy environment also suggests that the natural environment should be managed in such a way that enables people to live and work under conditions that will not harm their mental and physical health (du Plessis 2011, pp. 293-294). In general, it seems that the protection of communities from increasingly life-threatening environmental trends such as pollution and floods, all fall within the ambit of the duty imposed on local government to ensure a healthy environment. Ineffective legal and other responses to these lifethreatening environmental trends have the potential to negatively affect peoples' health through for example, the spread of diseases (Besada and Sewankambo 2009, pp. 16-20).

The constitutional requirement to clearly allocate responsibilities and tasks to the various spheres of government, framework and sector-specific environmental legislation and policies designed to give effect to section 24 of the Constitution usually requires local government to play a role in realising the objectives of the constitutional environmental right (du Plessis 2008, pp. 408-416). For example, the National Environmental Management Act (NEMA) 107 of 1998, South Africa's main framework environmental legislation, which applies to all spheres of government and organs of state, provides a principled framework for environmental governance at the local government level because it outlines environmental functions and duties for local government as well as a number of environmental law principles that should guide municipalities' interpretation, administration and implementation of environmental matters (du Plessis 2008, pp. 391-401). This implies that the environmental management principles contained in section 2 of NEMA should also guide the implementation of the section 24 constitutional environmental obligations by all organs of state, including municipalities (du Plessis 2008, p. 392). Therefore, the principles of environmental management outlined in section 2 of NEMA generally apply to all actions of all municipalities that have the potential to significantly affect the environment.

\section{The potential role of courts through the lenses of Le Sueur}

This part of the article uses the Le Sueur case to illustrate that litigation provides an opportunity for courts to expand the environmental powers and functions of municipalities beyond Schedules 4B and $5 \mathrm{~B}$ of the Constitution. It begins by briefly setting out the facts, decision and ratio decidendi of the court and then reflects on some valuable lessons for the future.

\section{Facts of the case}

One of the two issues that had to be dealt with in the Le Sueur case arose from a resolution adopted by the eThekwini Metropolitan Municipality on the 9 of December 2010 to amend its Town Planning 
Scheme by introducing the Durban Metropolitan Open Space System (D-MOSS). ${ }^{16}$ D-MOSS is a system of open spaces, comprising 74,000 hectares of land and water. It incorporates areas of high biodiversity value, linked together in a viable network of open spaces (eThekwini Municipality no date). Areas included in D-MOSS are nature reserves, forests, large rural landscapes in the upper catchments and riverine and coastal corridors. Some areas of privately owned land are included in DMOSS. D-MOSS was introduced to by the Municipality to contribute towards biodiversity conservation by inter alia meeting provincial and national biodiversity targets. D-MOSS provides a range of ecosystem goods and services to Durban residents. ${ }^{17}$

The applicants in this case were owners of property affected by the D-MOSS resolutions - largely worried that their property would be expropriated for that purpose. ${ }^{18}$ They argued before the Pietermaritzburg High Court that the decision to introduce D-MOSS should be declared unconstitutional and illegal and accordingly set aside. Their argument was based on two main reasons: the resolutions were taken in terms of Town Planning Ordinance No. 27 of 1947 which had by that date been repealed and replaced by the Kwazulu-Natal Planning and Development Act No. 6 of $2008 ;{ }^{19}$ and that the respondents lacked constitutional and legislative powers to legislate on environmental issues - especially those relating to conservation and biodiversity protection. ${ }^{20}$ In this context, attention is given to the second issue/argument raised.

The applicants argued that in introducing the D-MOSS Amendments, the Municipality had acted ultra vires its powers as it did not have law-making powers in the sphere of the environment. ${ }^{21}$ The applicants argued that the 'environment' is listed in Schedule 4A of the Constitution as a functional area of current national and provincial competence, therefore excluding municipalities from legislating in such area of activity. ${ }^{22}$ Furthermore, the applicants submitted that NEMA, South Africa's environmental framework law, does not accord municipalities law-making powers relating to environmental protection. It was argued that by creating the D-MOSS Amendments, the Metro had legislated for the protection of the environment and created its own process for authorising environmental related activities at a municipal level. The applicants submitted that the environmental powers and functions of national and provincial government are different and distinct from the planning powers and functions of municipalities. ${ }^{23}$ The applicants argued that the other related

\footnotetext{
${ }^{16}$ Le Sueur and Another, par 1.

${ }^{17}$ For details, see: What is the Durban Metropolitan Open Space System, eThekwini Municipality (no date).

${ }^{18}$ See Le Sueur and Another, pars 17-18.

${ }^{19}$ Le Sueur and Another, pars 3-4 and 5-15.

${ }^{20}$ See Le Sueur and Another, pars 3-4.

${ }^{21}$ See Le Sueur and Another, par 16.

${ }^{22}$ See Le Sueur and Another, par 16.

${ }^{23}$ See Le Sueur and Another, par 16.
} 
functional areas in respect of which municipalities have authority are air pollution; storm water management services; water and sanitation services; beaches; cemeteries; facilities for the accommodation, care and burial of animals; refuse removal, refuse dumps and solid waste disposal. They argued that although section 152(d) of the Constitution obliges municipalities to promote a safe and healthy environment, the constitutional areas of competence of municipalities do not extend to the area of 'environment' or 'nature conservation' or 'biodiversity protection'. ${ }^{24}$ The applicants argued further that in as much as D-MOSS Amendments relate to land which consists of 'indigenous forests', the 'administration of indigenous forests' is a National or Provincial functional area in respect of which the Municipality has no authority to legislate. The applicants contended that although there may be an overlap between regulation of land use and other functional areas, such overlapping does not give a municipality power to legislate in the overlapping functional areas. Based on the above reasoning, the applicants argued that in attempting to legislate on issues in relation to the environment, the Municipality had acted unconstitutionally and illegally. From this point of view, the applicants argued that the D-MOSS Amendments should be set aside as being unconstitutional and illegal. ${ }^{25}$

\section{Decision and 'ratio decidendi'}

Justice Gyanda concurred with the submission of the first respondent (eThekwini Metro) that the reasoning adopted by the applicants was unduly narrow and incorrect for several reasons. ${ }^{26}$ Firstly, the Court indicated that as an organ of state, each municipality is obliged to comply with the obligations imposed on the state by section 7(2) of the Constitution to "respect, protect, promote and fulfil" as well as the section 24 constitutional environmental right. ${ }^{27}$ Reference to the 'state' in section 7(2) includes the local sphere of government which is constituted by municipalities. The obligation imposed by sections 7(2) and 24(b) of the Constitution to inter alia promote conservation, secure ecologically sustainable development and use of natural resources do not only apply to national and provincial governments. The obligation extends to the local sphere of government. ${ }^{28}$ The Court indicated that a joint reading of several constitutional provisions - such as sections 7(2), 24, 152(d), 40, 41(1) and 43 - make it clear that the "functional areas of constitutional competence as set out in Schedules 4 and 5 of the Constitution are not the only provisions dealing with governmental responsibilities and duties". ${ }^{29}$ A joint reading of the above provisions makes it clear that

\footnotetext{
${ }^{24}$ See Le Sueur and Another, par 16.

${ }^{25}$ See Le Sueur and Another, par 16.

${ }^{26}$ Le Sueur and Another, par 19.

${ }^{27}$ Le Sueur and Another, par 19.

${ }^{28}$ Le Sueur and Another, par 19.

${ }^{29}$ Le Sueur and Another, pars 19 and 20.
} 
municipalities cannot legislate in conflict with section 24 of the Constitution and can implement policies and by-laws that seek to protect the environment against "improper invasion" ${ }^{30}$

In addition, the Court acknowledged that apart from matters listed in Schedules 4B and 5B of the Constitution, municipalities have powers to administer any matter assigned by national or provincial legislation. ${ }^{31}$ In this regard, matters reserved for national and provincial legislative competence which necessarily relates to local government can be assigned to a municipality (or to municipalities in general) if the criteria in section 156(4) of the Constitution have been met. In an implicit acknowledgement of the principle of institutional subsidiarity, the Court noted that municipalities "are in the best position to know, understand, and deal with issues involving the environment at the local level". ${ }^{32}$ The Court observed that the assignment of environmental powers and functions to municipalities, coupled with their incidental administrative powers, indicate that the legislative powers and functions of the three spheres of government are fluid and not watertight. ${ }^{33}$ The Court upheld the view that although the environment was not inserted in Schedules 4B and 5B of the Constitution, it "is an ideal example of an area of legislative and executive authority or power which had to reside in all three levels of government" and thus requiring co-operative government. ${ }^{34}$

Thirdly, the Court noted that municipalities have historically exercised within their jurisdictions legislative and executive responsibility over environmental issues under the banner of 'municipal planning', a fact recognised in the manner in which the newer constitutional dispensation was designed..$^{35}$ The Court observed that both at the time that the Constitution was adopted and subsequent thereto, national and provincial legislation and policies have allocated municipalities a legislative and executive mandate with respect to environmental matters (including biodiversity conservation), placing such matters squarely within the concept of municipal planning. ${ }^{36}$ Based on this historical consciousness, the Court held that it is clear that when the functional areas were allocated in Schedules 4 and 5, the framers of the Constitution knew that 'municipal planning' encompassed environmental considerations. ${ }^{37}$

In this regard, Chapter 5 of the Municipal Systems Act which is dedicated to integrated development planning, specifically in section 23(1)(c), oblige municipalities to contribute, together with other organs of state, to the progressive realisation of the constitutional environmental right. The Court held

\footnotetext{
${ }^{30}$ Le Sueur and Another, par 19.

${ }^{31}$ See Le Sueur and Another, par 20.

${ }^{32}$ See Le Sueur and Another, par 20.

${ }^{33}$ See Le Sueur and Another, par 20.

${ }^{34}$ See Le Sueur and Another, par 20.

${ }^{35}$ See Le Sueur and Another, pars 21 and 39.

${ }^{36}$ See Le Sueur and Another, pars 22, 30 and 39.

${ }^{37}$ See Le Sueur and Another, pars 22-24 and 39.
} 
that this was a clear mandate from national legislation obliging municipalities to promote environmental objectives. ${ }^{38}$ The Court also recognised that municipalities have spatial planning powers and can rezone land in line with their spatial development frameworks which must be consistent with their IDPs as well as provincial and national legislation. ${ }^{39}$ The Court noted that DMOSS was introduced in line with the municipality's IDP requirements and that the law makes provision for environmental issues to be addressed in the IDP of every municipality. ${ }^{40} \mathrm{Judge}$ Gyanda accepted the view that "it is impossible as a matter of accepted town planning practice to divorce environmental and conservation concerns from town planning principles". ${ }^{41}$ The Court established that D-MOSS did not conflict with any national or provincial legislation/policy. ${ }^{42}$ Based on this analysis, the learned judge held that:

In the result, I am satisfied that the first respondent has proved that prior to the advent of the Constitution 'Municipal Planning' involved the power to regulate landuse whilst taking into account, amongst other things, the need to protect the natural environment. It is clear that the term 'Municipal Planning' encompassed that meaning when used in the Constitution. I am accordingly in full agreement with the first respondent's submission that it is impossible to separate environmental and conservation concerns in town planning practice from a 'Municipal Planning' perspective. ${ }^{43}$

In addition to the above reasons, the Court recognised that the national environmental management principles outlined in section 2 of NEMA apply to actions of all organs of state that may significantly affect the environment - including the actions of municipalities. ${ }^{44}$ Apart from these general principles, there are specific provisions of NEMA as well as other legislation, policies and regulations which specifically recognise the duties of municipalities with regard to the environment in its municipal planning function. ${ }^{45}$ Based on these duties, the Court held that municipalities are entitled to regulate environmental matters from the micro level for the protection of the environment.

Based on the three main reasons discussed above, the judge held that municipalities are in fact authorised to legislate in respect of environmental matters to protect the environment at the local level and that the D-MOSS Amendments did not in any way transgress or intrude upon the exclusive purview of the national and provincial government in respect of environmental legislation or policy. The judge held that the D-MOSS amendments introduced by the first respondent was not

\footnotetext{
${ }^{38}$ Le Sueur and Another, par 24.

${ }^{39}$ Le Sueur and Another, pars 25-28.

${ }^{40}$ Le Sueur and Another, pars 27-29.

${ }^{41}$ Le Sueur and Another, pars 29 and 33.

${ }^{42}$ Le Sueur and Another, pars 27-29.

${ }^{43}$ Le Sueur and Another, par 33.

${ }^{44}$ Le Sueur and Another, par 34.

${ }^{45}$ Le Sueur and Another, pars 37-38.
} 
unconstitutional and invalid on the basis contended by the applicants, namely, that the first respondent did not have the authority to legislate in this regard. ${ }^{46}$ The Court dismissed the application with costs.

\section{Lessons and potential role for courts}

A number of lessons could be drawn from the Le Sueur case discussed above. The most obvious lesson is that the environmental powers and functions of municipalities cannot be defined exclusively with reference to the Schedules in the Constitution. As Justice Gyanda put it in the Le Sueur case, Schedules 4 and 5 of the Constitution are not the only provisions dealing with governmental responsibilities and duties. Any analysis of local government's environmental powers and duties cannot be exhaustive without a consideration of the implications of section 7(2) and 24 of the Constitution. The socio-economic rights jurisprudence of courts is useful in understanding the powers and functions of municipalities in relation to the environment. It should be noted that, in broad terms, the methodology used by Justice Gyanda in Le Sueur resonates with that of the Constitutional Court in the Blue Moonlight case. Although Blue Moonlight Properties did not deal with environmental matters ${ }^{47}$ it is important in this context because the Constitutional Court clearly indicated that the powers and functions of municipalities in socio-economic rights cases (specifically the right of access to housing) go beyond the rigid confines of Schedules $4 \mathrm{~B}$ and $5 \mathrm{~B}$ of the Constitution. ${ }^{48}$

The Constitutional Court held that the legislative and executive powers and functions of municipalities must be understood in the context of the entire constitutional framework, its earlier socio-economic rights jurisprudence and the specific obligations imposed by national and provincial legislation as well as policies on local government. ${ }^{49}$ By analogy, the reasoning of the Constitutional Court in the Blue Moonlight case extends to the environmental constitutional right because of its socio-economic rights character (du Plessis 2011, pp. 279-307) and the similar (albeit not uniform) nature of the obligations imposed by the Constitution, legislation and policies on municipalities to contribute towards the realisation of the rights entrenched in sections 24, 25, 26, 27 and 29 of the Constitution. ${ }^{50}$ Therefore, the position adopted by the Pietermaritzburg High Court in Le Sueur in relation to how to understand the legislative and executive environmental powers and functions of municipalities is similar to that earlier adopted by the Constitutional Court in Blue Moonlight in the context of the right of access to housing. In any event, Schedules $4 \mathrm{~B}$ and $5 \mathrm{~B}$ of the Constitution are non-exhaustive of local government's executive and law-making powers and functions.

\footnotetext{
${ }^{46}$ Le Sueur and Another, par 40.

${ }^{47}$ For facts of the case, see Blue Moonlight Properties 39 (Pty) Ltd, pars 1-9.

${ }^{48}$ Blue Moonlight Properties 39 (Pty) Ltd, pars 20-28, 42-67.

${ }^{49}$ Blue Moonlight Properties 39 (Pty) Ltd, pars 20-28, 42-67.

${ }^{50}$ See for example, s 23(1)(c) of the Systems Act. While the wording of the socio-economic entitlements in sections 26(1), 27(1) and 29(1) of the Constitution leaves them subject to progressive realisation, this is not the case with the s 24 constitutional environmental right.
} 
In addition, one can draw from Le Sueur and the Constitutional Court's socio-economic rights jurisprudence in Blue Moonlight Properties that there is nothing which prevents municipalities that have the necessary resources to self-fund environmental projects that typically fall within the legislative area of competence of national and provincial government - as defined by Schedules $4 \mathrm{~A}$ and $5 \mathrm{~A}$ - in so far as such projects seek to further the objectives of section 24 of the Constitution ${ }^{51}$ and are not in conflict with national and provincial programmes. It now appears that, when exercising its original and assigned powers and functions, a municipality can adopt bylaws to protect against improper invasion any environmental matters listed in Schedules 4A and 5A of the Constitution in so far as this relates to its functions and to the extent that the bylaw does not conflict with a provincial and national legislation. ${ }^{52}$ This is connected to the incidental administrative powers conferred on municipalities by section 156(5) of the Constitution. A close reading of the Constitutional Court's jurisprudence in City of Cape Town $v$ Robertson suggests that a municipality can do anything to foster constitutional objectives provided such action is not illegal. ${ }^{53}$ By providing more 'room' for non Schedule 4B / 5B activities for local government, courts help to better position municipalities for the pursuit of NEMA's objectives in combination with the rights in the Bill of Rights - including the environmental right. The approach of courts help municipalities that are willing and capable, to be able to see to their fulfilment of s 24 of the Constitution where the lists in the Schedules tend to make this difficult for local government in some areas - such as biodiversity conservation.

Thirdly, it is also evident that municipal planning is inextricably linked to environmental issues and could be used to foster environmental objectives. ${ }^{54}$ In Le Sueur, the learned judge traced this link to statutes enacted before and during the local government transition period. ${ }^{55}$ This historically selfconscious approach to the interpretation of the planning and environmental powers and functions of municipalities is also complemented by the number of sector-specific environmental plans that are supposed to be part of local government integrated development planning - Spatial Development Frameworks, Waste Management Plans, Air Quality Management Plans and Biodiversity Plans must all be aligned to the IDP (Fuo 2014, pp. 351-357).

Fourthly, although the jurisprudence of courts in Le Sueur and Blue Moonlight Properties clearly indicate that the powers of municipalities in fostering environmental objectives go beyond Schedules $4 \mathrm{~B}$ and $5 \mathrm{~B}$ of the Constitution, the intricacies of such powers have not been exhaustively defined. This will continuously be defined over time by way of legislation, policies and judicial interpretation.

\footnotetext{
${ }^{51}$ See Blue Moonlight Properties 39 (Pty) Ltd, pars 53, 57 and 67.

${ }^{52}$ See Le Sueur and Another, par 19.

${ }^{53}$ City of Cape Town and Other v Robertson, par 60.

${ }^{54}$ Le Sueur and Another, pars 22-24 and 30-33.

${ }^{55}$ Le Sueur and Another, pars 22-24, 30-33 and 39.
} 
The contribution the judiciary has made towards clarifying the constitutional environmental powers and functions of municipalities in Le Sueur (and Blue Moonlight Properties, by way of analogy) show that courts have the potential to contribute towards delineating the contours of local government's constitutional environmental powers and functions beyond Schedules 4B and 5B of the Constitution. This can be achieved by purposively interpreting existing functions in Schedules 4B and 5B of the Constitution or through interpretations of local government's responsibilities in relation to s 24 of the Constitution. Such interpretations may redefine in a more concrete manner the role of municipalities in giving effect to the section 24 constitutional environmental rights.

Litigation provides courts an opportunity to overturn any existing laws or policies that unduly limit the role of municipalities in fostering the objectives of section 24 of the Constitution, especially where environmental issues directly affect local communities. In addition, environmental litigation may be used to enforce underutilised legal principles such as the principle of institutional subsidiarity located in section 156(4) of the Constitution. This may pave the way for the assignment of more environmental functions to municipalities where all the prescribed criteria for assignment have been met. However, environmental litigation remains only one of the tools that can be used to further define the constitutional environmental powers and functions of municipalities. Political lobbying may herald legislation and policies that provide greater clarity on local government's constitutional environmental powers and functions. In the meantime, intergovernmental cooperation should play a pivotal role in addressing tensions that arise especially where there is uncertainty over the boundaries of local government's constitutional environmental powers and functions. Conflicts abound due to the fact that the powers and functions of the three spheres of government in relation to the environment are not hermetically sealed.

\section{Conclusion}

The Constitution places local government at the forefront of sustainable development in South Africa. This is evident from the objects of local government and the obligation placed on all spheres of government to use legislative and other measures to give effect to the broad objectives of section 24 of the Constitution. Despite these broad constitutional obligations, the exact scope of local government's constitutional environmental powers and functions are not always clearly defined. Drawing lessons from Le Sueur, this article argues that environmental litigation provides courts an opportunity to redefine the powers of municipalities in fostering constitutional environmental objectives in South Africa. It argues that despite the important role of courts, intergovernmental cooperation is important in clarifying the powers and functions of South African municipalities. 


\section{References}

Besada, H. and Sewankambo, N. (2009) Climate change in Africa: Adaptation, mitigation and governance challenges. Waterloo, Ontario: Centre for International Governance Innovation.

Carpenter, G. (1999) Cooperative government, devolution of powers and subsidiarity: The South African perspective. In: Konrad Adenauer Foundation Subnational Constitutional Governance. Proceedings of a Conference on Subnational Constitutional Governance. St Georges Hotel-Rietvlei Dam Pretoria, 16-18 March, 1999. South Africa: Konrad Adenauer Foundation, pp. 45-52.

Christmas, A. and de Visser, J. (2009) Bridging the gap between theory and practice: Reviewing the functions and powers of local government in South Africa. Commonwealth Journal of Local Governance, 2, 107119. doi: http://dx.doi.org/10.5130/cjlg.v0i2.999

City of Cape Town and Other $v$ Robertson and Other. (2005) (2) SA 323 (CC).

City of Johannesburg Metropolitan Municipality v Blue Moonlight Properties 38 (Pty) Ltd and Another. (2012) (2) BCLR 150 (CC).

Constitution of the Republic of South Africa. (1996) Cape Town: Juta \& Co Ltd.

Department of Provincial and Local Government (now Department of Cooperative Governance and Traditional Affairs). (2004) White Paper on municipal service partnerships. Republic of South Africa.

de Visser, J. (2003) A perspective on local government's role in realising the right to housing and the answer of the Grootboom judgment. Law, Democracy and Development, 7 (2), 201-215.

de Visser, J. (2005) Developmental local government: A case study of South Africa. Antwerpen: Intersentia.

de Visser, J. (2008) Institutional subsidiarity in the constitution: Slapstick asymmetry or a 'rights-based' approach to powers? Cape Town: Community Law Centre.

de Visser, J. (2009) Developmental local government in South Africa: Institutional fault lines. Commonwealth Journal of Local Governance, 2, 7-25. doi: http://dx.doi.org/10.5130/cjlg.v0i2.1005

de Visser, J. (2010) Institutional subsidiarity in the South African constitution. Stellenbosch Law Review, 1, 90115.

de Wet, E. and du Plessis, A. (2010) The meaning of certain substantive obligations distilled from international human rights instruments for constitutional environmental rights in South Africa. African Human Rights Law Journal, 10, 345-376.

du Plessis, A. (2008) Fulfilment of South Africa's constitutional environmental right in the local government sphere. $\mathrm{PhD}$ Thesis, North West University.

du Plessis, A. (2010) Local environmental governance and the role of local government in realising section 24 of the South African Constitution. Stellenbosch Law Review, 2, 265-297.

du Plessis, A. (2011) South Africa's constitutional environmental right (generously) interpreted: What is in it for poverty. South African Journal on Human Rights, 27 (2), 279-307.

du Plessis, W. and du Plessis, A. (2011) Striking the sustainability balance in South Africa. In: Faure, M. and du Plessis, W. (eds) The balancing of interest in environmental law in Africa. Pretoria: Pretoria University Law Press. pp. 413-458.

eThekwini Municipality. (no date) What is the Durban Metropolitan Open Space System. [Online] Available at: http://www.durban.gov.za/City_Services/development_planning_management/environmental_planning_ climate_protection/Durban_Open_Space/Pages/-What-is-the-Durban-Metropolitan-Open-SpaceSystem.aspx [Accessed 20 October 2015].

Fedsure Life Assurance Ltd and Others v Greater Johannesburg Transitional Metropolitan Council and Others. (1998) (12) BCLR 1458.

Fuel Retailers Association of Southern Africa v Director-General: Environmental Management, Department of Agriculture, Conservation and Environment, Mpumalanga Province and Others. (2007) (10) BCLR 1059 (CC). 
Fuo, O. (2013) Constitutional basis for the enforcement of executive policies that give effect to socio-economic rights in South Africa. Potchefstroom Electronic Law Journal, 16 (4), 1-44. doi: http://dx.doi.org/10.4314/pelj.v16i4.1

Fuo, O. (2014) Local government's role in the pursuit of the transformative constitutional mandate of social justice in South Africa. PhD Thesis, North-West University.

Government of the Republic of South Africa and Others v Grootboom and Others. (2000) 11 BCLR 1169 (CC).

Joseph and Others $v$ City of Johannesburg and Others. (2010) (3) BCLR 212 (CC).

Kidd, M. (2006) Greening the judiciary. Potchefstroom Electronic Law Journal, 9 (3), $72-87$.

Kotze, L. and du Plessis, A. (2010) Some brief observations on fifteen years of environmental rights jurisprudence in South Africa. Journal of Court Innovation, 3 (1), 157-176.

Langa, J. (2006) Transformative constitutionalism. Stellenbosch Law Review, 17 (3), 351-360.

Le Sueur and Another v eThekwini Municipality and Others. [2013] ZAKZPHC 6 (30 January 2013).

Local Government: Municipal Structures Act 117 of 1998. Cape Town, Government of the Republic of South Africa.

Local Government Municipal Systems Act 32 of 2000. Cape Town, Government of the Republic of South Africa.

Maccsand (Pty) Ltd $v$ City of Cape Town and Others. (2012) (7) BCLR 690 (CC).

Malan, L. (2005) Intergovernmental relations and co-operative government in South Africa: The ten year review. Politeia, 24 (2), 226-243.

Minister of Local Government, Environmental Affairs and Development Planning, Western Cape v Habitat Council and Others. (2014) (4) SA 437 (CC).

Minister of Local Government, Western Cape v Lagoonbay Lifestyle Estate (Pty) Ltd and Others. (2014) (1) SA $521(\mathrm{CC})$.

Mkontwana v Nelson Mandela Metropolitan Municipality. (2005) (2) BCLR 150 (CC).

Municipal Fiscal Powers and Functions Act 12 of 2007. Cape Town, Government of the Republic of South Africa.

National Environment Management: Air Quality Act. (NEMAQA) 39 of 2004. Cape Town, Government of the Republic of South Africa.

National Environmental Management: Biodiversity Act. (NEMBA) 10 of 2004. Cape Town, Government of the Republic of South Africa.

National Environmental Management Act (NEMA) 107 of 1998. Cape Town, Government of the Republic of South Africa.

National Environmental Management: Protected Areas Act (NEMPAA) 57 of 2003. Cape Town, Government of the Republic of South Africa.

National Environmental Management: Waste Act (NEMWA) 59 of 2008. Cape Town, Government of the Republic of South Africa.

Rates Action Group v City of Cape Town. (2007) 1 All SA 233 (SCA).

Steytler, N. and de Visser, J. (2009) Local government law of South Africa. Issue 2. Durban: LexisNexis.

Steytler, N. and Fessha, Y. (2005) Defining provincial and local government powers and functions: The management of concurrency. Cape Town: Multi-Level Government Initiative.

Urquhart, P. and Atkinson, D. (2002) A pathway to sustainability: Local Agenda 21 in South Africa. Cape Town: University of Cape Town. 